\title{
Designing Viable Republican Constitutions for Modern African States: Why the Institution of Traditional Kingship Must Be Abolished
}

\author{
Jare Oladosu*
}

\begin{abstract}
In this paper I argue for the adoption of an unmitigated republican constitutional system by modern African nation states as a necessary condition for the realisation of their democratic aspirations. I identify the continued retention of the traditional kingship institution, even in a much whittled down form, as a major impediment to the establishment of full-fledged republics in contemporary Africa. I then argue for the total abolition of the kingship system on the following grounds: (i) that it was founded on historical injustice to begin with, (ii) that it has no relevance or utility to modern African states, and (iii) most importantly, that its continued existence is antithetical to the requirements of a modern democracy. This last point, I take largely for granted. I provide a short elucidation of 'republicanism' as a constitutional philosophy. Finally, I suggest some constitutional measures that African nation states may adopt to eradicate the traditional kingship institution and thereby ensure the survival and flourishing of their republics.
\end{abstract}

\section{Résumé}

Dans cet article, je soutiens l'adoption d'un système constitutionnel républicain absolu par les états nations africains modernes, comme condition nécessaire à la réalisation de leurs aspirations démocratiques. Je considère le maintien de l'institution traditionnelle de la royauté comme un frein majeur à l'établissement de véritables républiques en Afrique contemporaine. Ensuite, je soutiens

\footnotetext{
* Department of Philosophy, Obafemi Awolowo University, Ile-Ife, Nigeria.

Email: jare2dosu@yahoo.com
} 
l'abolition totale du système de la royauté pour les raisons suivantes : (i) je me suis avant tout basé sur l'injustice historique; (ii) ce système n'est d'aucune utilité ou pertinence pour les états africains modernes, et (iii) son maintien est antithétique aux exigences d'une démocratie moderne. Je considère que ce dernier point va de soi. Je propose une brève explication du terme « républicanisme » en tant que philosophie constitutionnelle. Enfin, je propose des mesures constitutionnelles que les états nations africains doivent adopter, afin de supprimer l'institution de la royauté et ainsi assurer la survie et l'épanouissement de leurs républiques.

\section{Introduction}

The fact that Africa ${ }^{1}$ is bedevilled by a multitude of problems has become, in a perverse sort of way, an axiom of social and political discourse on the continent. Africa is the continent that cannot feed or clothe itself; it is the continent where development theories and programmes tested and successful everywhere else have failed; it is the continent where diseases and afflictions like HIV/AIDS ravage entire demographic segments; it is the only continent where life expectancy is decreasing, even as it is rising everywhere else, mid-way into the first decade of the twenty-first century. More pertinent for the purposes of this paper, Africa, it seems, is a politically confused continent.

The focus of this paper is on this more fundamental failing, namely, Africa's seeming inability to govern itself well. It is my contention that the political frustration, instability and chaos characteristic of the African world is, to a significant extent, at the root, a failure of philosophy, specifically, a failure of constitutional philosophy. Until modern African nation states get their political and constitutional philosophies right, not much progress will be recorded at the level of practical governance. In the post-colonial African societies, no task could be more urgent than the imperative of designing viable constitutions to serve as the legal framework for the political and social organisation of the emerging nation states. African philosophers, jurists and political scientists have an important role to play in the indispensable initial process of theoretical review and self-evaluation. My objective in this essay is to make some modest contribution in this regard, by arguing for the adoption of a full-fledged republican constitutional order by contemporary African states.

At independence, the newly 'formed' African nation states had three main constitutional options. The first was to revert to the pre-colonial 
political order, which in many of the large African societies would be some form of hereditary monarchy. The second was to adopt a fully (unmitigated) republican constitution - with the 1787 post-revolutionary Constitution of the United States as a tantalising model. The third option was to fashion out some constitutional hybrid, which would incorporate elements of the republican model with aspects of the traditional kingship systems. On paper, nearly all African nation states today proclaim themselves to be modern republics. But whereas republicanism was an auspicious component of the rhetoric of anti-colonial liberation struggles in Africa, the reality in most cases was the subsequent adoption (after the attainment of political independence) of a mixed constitution. What we have in many African states today, as Ajume Wingo has correctly remarked, is 'a myriad of indigenous systems of government with superimposed foreign structures' (Wingo 2004: 450).

Among contemporary theorists and commentators on African social and political systems, the position of choice seems also to be the defence of some form of a mixed constitution. ${ }^{2}$ Constitutional fundamentalism, as Wingo would describe it, either in the form of advocacy for '... a total return to the African past', or the polar opposite, ... a total unmitigated acceptance of Western political arrangements', is less appealing. In general, writers on African constitutional and political theory tend to agree with Wingo that '... a well-ordered liberal democracy should be built on deeply rooted African traditions' (Wingo 2004: 450).

This has usually been understood to mean the continued retention of the institution of traditional kingship, no matter how incompatible it is with the imperatives of a modern democracy.

Against this popular current, I will, in this paper, defend an 'extremist' position; I will argue for the adoption of an unmitigated form of republicanism. I assume that modern Africans, like people everywhere, desire - or at least ought to desire - democratic governance. If that is so, then the motivation for the thesis of this paper can be easily stated: my defence of republicanism is informed by a fundamental conviction, namely, that only a full-fledged republican order can provide the constitutional anchor for true democracy.

By its nature, republicanism is opposed to all forms of despotism or social and political domination, whether the despotism is in the form of an absolute monarchy, a military dictatorship, or a theocracy. The first crucial step in the establishment of a republican order in African states is to subdue, or better still, eliminate, the sources of despotism, 
represented, for example, by the institution of traditional kingship, state sponsorship of religious creeds, an overbearing, insubordinate military, and the neo-colonial global forces of economic and social domination. Each of these popular sovereignty-impairing conditions deserves serious scholarly attention; and none has, to my mind, received adequate analysis. However, my focus in this paper is on the institution of traditional rulers and chiefs in African societies. My contention is that this institution and the principles of republicanism are mutually incompatible.

The remainder of the paper will proceed as follows. Part two will be a discussion of the very resilient institution of traditional kingship in Africa. My objective here is to argue for its total eradication, or at least its relegation to the nominal status of historical relic, attracting no more than the role of a cultural reminder and occasional source of entertainment. Properly harnessed, the institution could be a contributor to the tourist economy. But it should attract no political value or significance whatsoever. In part three, I provide a short analysis of the concept of republicanism. Other than the conceptual elucidation, I also suggest a number of deliberate legal and constitutional measures that African republics could take to promote the growth of republicanism.

\section{The Case against the Traditional Kingship Institution}

Now that Africa is politically de-colonised and the process of democratisation is well under way in many African countries, what should we do with our traditional rulers and the traditional kingship institution? For African scholars, the significance of this question is clearly beyond the mere satisfaction of intellectual curiosity; matters of immediate practical import are at stake in the disposition of the question. I may repeat my own preferred answer to the question. African societies are desirous of democracy. Democracy can only thrive in a republic, in other words, republicanism is a necessary condition for the survival of democracy. In turn, the eradication of the traditional kingship institution is a necessary prerequisite for the establishment of a republican order. Therefore, the institution of traditional kingship or monarchy has to be abolished for democracy to succeed in African nation states.

It is advisable to start by acknowledging that to raise questions about the origin, historical role, and contemporary relevance of the traditional kingship institution in African societies is, in the eyes of thoroughbred traditionalists and cultural romantics, to commit an abomination. It is 
to reveal oneself as a cultural heretic or traitor. Are our traditional rulers not the Kabiesi - the ones who may not be called upon to account for their deeds? Who then but a sacrilegious modernist dares to probe into such sacred matters - matters ordinarily beyond the full understanding of mere mortals? But this impulsive disdain for any attempt at critical scrutiny of the kingship institution in Africa is instructive. If the institution is indeed justly constituted, if truly it has a track record of achievements, if it has conferred benefits on generations of Africans, then the appropriate response of its defenders should be to showcase the justice at its foundation, as well as its record of achievements and contemporary relevance or utility. Could it be then that the impulsive flight into fury is borne out of fear? The fear may be that the inquisitive questioner might succeed in exposing the rotten underbelly of an inherently unjust social institution - 'a government of wolves over sheep' as Thomas Jefferson ${ }^{3}$ once described a system of hereditary monarchy; a cultural albatross which we would have had to throw off anyway as other civilisations have done, with or without the colonial experience, and which we cannot now jettison soon enough. The fear, as an English gentleman once remarked (appropriately in connection with the British monarchy) that the questioner might be letting daylight in on magic.

It is my contention that the institution of traditional kingship in Africa was founded either on the coercive imperatives of might and naked force, being the prize of war and conquest, or on what we may describe as spiritual deception, the practical manifestation of a dubious theology.

Examples of monarchies founded on war and conquest abound all over Africa. I cite two well-known cases from Nigeria. Probably the most documented case is that of the Fulani warriors (Jihadists) of the Sokoto Caliphate, who overran virtually the whole of Northern Nigeria, establishing emirates in the conquered territories. The other example is the monarchy in Ibadan land (see Akinyele 1971) in southwestern Nigeria. The Ibadan kingship institution offers a compelling case study in the metamorphosis of a monarchical system. Though at present the largest city in West Africa, Ibadan is a relatively new settlement. It was a nineteenth century creation, essentially a military camp at its inception. Indeed, it was the Ibadan warriors who checkmated the southwards advances of the warriors of the Sokoto Caliphate, after the Caliphate's army had successfully sacked the capital city of the old Oyo Empire. How the prevailing pattern of ascension to the throne of 
Ibadan emerged is not too clear, but the first monarchs of Ibadan were, no doubt, the more resourceful war lords. Today, however, the Olubadan, a royal throne built on military conquest and pillage, is a first class Oba (king) in Oyo State, with a long line of people waiting eagerly for their turn to ascend the sacred throne vacated by their ancestors. ${ }^{4}$

The other foundation of the African kingship institution is much grander in conception and intellectual pretence. The origin of the traditional rulership institution on this account is supposedly so noble that the monarchs are to be credited with the divine right to reign as the legally-illimitable, supreme sovereigns over their subjects. This account of the origin of the hereditary kingship system is usually derived from the cosmologies and ancient mythologies of various African peoples. Again, I relate one such story with which I am most familiar. ${ }^{5}$

According to Yoruba cosmology and accounts of creation, a number of Yoruba monarchs derive their legitimacy as sovereign rulers by virtue of their divine pedigree. The primogenitor of these eminent monarchs, so the story goes, was actually a god who was sent down here to accomplish a sacred mission of propagating earthily existence.

In the beginning all that was, existed on the heavenly plain; what later became earth was a barren firmament of water and void. Then Olodumare, the Supreme Being, or Godhead decided to create earth and all the things in it, living and non-living. Olodumare commissioned some of His lieutenants - the lesser gods - to come down to perform the sacred task. The leader of the task force that came down from heaven was Oduduwa. Oduduwa came climbing down on a chain ${ }^{6}$ and landed at present day Ile-Ife, with the paraphernalia of creation in his rucksack. The materials included some quantity of earth, to be poured on the barren water to form solid ground, a hen to help spread it around, ${ }^{7}$ and a chameleon to perform the all-important but delicate task of testwalking the newly formed ground. This is why Ile-Ife is widely regarded as the cradle of the Yoruba race and civilisation, the source from where all Yoruba people migrated to other parts of the world where they are to be found today.

Oduduwa was the first Oba (monarch) at Ile-Ife. The Ooni of Ife is still addressed as the Arole-Oduduwa, the chief custodian of the household of Oduduwa. It was from Ile-Ife that the children and grandchildren of Oduduwa departed to found their own empires and kingdoms. Since those Ife princes and their descendants were, and are still supposed to be, the direct descendants of a being who was essentially a 
god, not only would these royal offspring have the royal blue blood flowing in their veins, presumably they are also the proud carriers of godly genes. That is why their authority as supreme rulers and lawgivers may not be challenged; that is why their sovereignty is thought to be absolute.

As mythologies go, the Yoruba account of creation would rival any account from any other civilisation in poetic resonance and imaginative force. The legendary African capacity for story-telling is here on full deployment. And if ever characters in a story line are awarded medals for their author's display of raw creative genius, then Oduduwa and his fellow travellers - our own illustrious ancestors and gods - would deserve a place on the front row in a stuntman's hall of fame, standing shoulder to shoulder with the gods of Homer. The only problem with the story is that it is not believable.

The entire story simply evaporates once subjected to the most cursory test of critical scrutiny, much as an early morning African mist dissipates under the assault of a shaft of sunlight. The first thing to note is the sheer incredulity of Oduduwa's gravity-defying mode of transportation down to earth from the heavenly realm. The chain on which Oduduwa purportedly climbed down from heaven must have been one heck of a long chain; and going by the evidence of modern science, it is not clear to what the other end of the chain was fastened. But apart from the matter of whether Oduduwa's chain was anchored on something or nothing - stuff that science fiction is made of - we must also wonder where Oduduwa's first population of subjects came from. If Oduduwa became the first monarch at Ile-Ife there would have to have been other human beings to be his subjects. (Has anyone heard of a monarch without subjects?)

According to one version of the story, all Yoruba people are supposed to be the descendants of Oduduwa. This line enjoys a very popular mass appeal, for reasons not too far to seek: it serves obvious sociological purposes of rallying the members of the Yoruba race (the in group') against external forces of national political rivalry and contestation. But then again, this version of the story just cannot be true. For if it is true, then all Yoruba men and women should be princes and princesses, legitimate aspirants to the royal thrones in Yorubaland. What then happened somewhere along the historical line, so that in every town and city in Yorubaland only a few lineages qualify as ruling houses whose members may ascend a royal throne, while the majority of the 
people in the town or city can only be mere subjects, or worse, descendants of freed slaves? That version of the story would also raise the issue of how Oduduwa alone was able, within his life span, to father enough offspring to fill a kingdom. How many wives accompanied Great Grand Pa Oduduwa on his journey of creation?

Surely, it makes more sense to suppose that there were already people around at Ile-Ife when Oduduwa got there. However, once we admit the existence of pre-Oduduwa people at Ile-Ife, the entire story explodes, much as Isaac La Perere's pre-Adamite theory (see Popkin 1968) exploded the Biblical account of creation and the entire corpus of JudeoChristian cosmology. Moreover, the admission of pre-Oduduwa people at Ile-Ife would tend to reduce this second purported foundation of the legitimacy of the hereditary kingship system in Yoruba land to the first. Oduduwa might just be conceived as another rampaging warlord, who came and established dominion over an indigenous population.

I have examined two possible bases of the legitimacy of the institution of hereditary kingship or monarchy in Yorubaland - I know of no other - and neither would indicate that the institution was founded on justice. Whether it is conceived as an aspect of the spoils of war and subjugation, or as an elaborate cosmo-theological ruse, there can be nothing morally legitimate at the foundation of the institution of hereditary monarchy among the Yoruba people of south-western Nigeria. I believe that this conclusion could be extrapolated to other parts of Africa. In any case, it is one who wishes to insist that the institution is morally just in origin or in conception that must bear the burden of proof.

Let us now turn our attention away from the moral foundations of the institution to its social utility (in the course of African history) and its contemporary relevance. 'Consider the contents of the Red Book in England, or the Almanac Royal in France', Thomas Jefferson once admonished his countrymen, 'and say what a people gain by monarchy' (cited in Popkin and Stroll 1984: 395). In respect of the vast majority of the populations of African kingdoms and empires, we must ask then, what have these people gained from their subjection to the traditional rulers? We may detest the moral rot at the foundation of the institution, but if it can be shown to be the harbinger of real benefits and the good life to those subjected to it, there may yet be a case to be made for it on strictly utilitarian grounds. 
At this point, a sharp contrast emerges between African emperors and kings and their European counterparts. While it is true that Europe's monarchs were (some still are) as opportunistic and predatory as African kings and princes, it is also the case that Europe's kings may justly be credited with the development of great civilisations. They were known to have commissioned the building of magnificent structures, many of which still stand. Peter the Great, Russia's most famous Emperor, personally supervised the design and construction of the city of St. Petersburg, located in an otherwise uninhabitable, reptile-invested swamp. St. Petersburg (christened Leningrad by the communists) is still today Russia's second most important city and cultural nerve-centre. European royals were generous sponsors of scientific research and great supporters of the adaptation of science for technology. If European technology was superior to what obtained in Africa when the two civilisations came into contact, Europe's kings and emperors deserve some of the credit. Up to the present-day, some funding organisations still retain their old names as royal academies, long after the monarchies under whose aegis they were founded are no more. Europe's emperors were great patrons of the arts and humanities. Many of the most memorable symphonies were composed at royal behest. The King James Version of the Bible, perhaps more than any other text, has contributed greatly to the propagation of the Christian theology.

By contrast, not much has been recorded as the contribution of African kings and princes to the building of the material structures of civilisation, or the development of its intellectual components. For the most part, it seems that the royals in African history have been content to just feed off the backs of their subjects. Many members of African royal houses merely savoured the best that the world had to offer, without adding a scintilla of value to it.

The situation is in fact worse than that. If we focus critical attention on selected periods in our past and contemporary history, we discover that the conduct of African emperors and kings has not always been noble.

A poignant case in point was the contribution of many African traditional rulers to the entrenchment of European colonialism, and the subsequent successful prosecution of the colonial subjugation of African peoples, and the plunder of the resources of our land. There is ample historical evidence to support what I would call the collaborationist thesis; the idea that many African traditional rulers 
were active collaborators with the foreign exploiters of colonial Africa. ${ }^{8}$ According to Akin Alao, 'As a strategy for efficient and effective administration the colonial government sought to involve indigenous chiefs in the administration of their towns under the direct supervision and authority of British administrators' (Alao undated: p. 7). To provide the necessary legal backing for the British policy of 'Indirect Rule' in Southwestern Nigeria, to cite one example, the Native Council Ordinance was enacted in 1901. Just as the British had intended it, "the activities of the Native Council contributed to a successful establishment of colonial rule in South Western Nigeria' (ibid p.8).

In time, there developed a symbiotic relationship between the British Administrators of the colonial government and the African traditional rulers. As Alao puts it, on one hand, 'the opinion of the chiefs were heavily relied upon by the British Administrators in preference to the wish of the educated elite in the Yoruba society'. On the other hand, 'on their ... part, the Yoruba chiefs now sought the support and understanding of British officials to remain in office even when they were unpopular with their own people' (ibid p.9).

To appreciate how enormously successful the policy of Indirect Rule was in the Western and Northern parts of Nigeria where the British first tried it, we need only recall that the system was subsequently extended to Eastern Nigeria. Since the people of Eastern Nigeria had no tradition of centralised kingdoms and monarchies, the British created these institutions de novo, with the introduction of the so-called Warrant Chiefs. Now the fact that the British considered African traditional practices as primitive, indeed fetish, was too well-known. British contempt for anything African then was scarcely disguised. So, why else would they want to replicate an indigenous African institution unless, as Alao has suggested, "many of the Native Councils [had indeed become] useful instruments of colonial control and domination' (ibid p.13)? Incidentally, in Eastern Nigeria too, institutional metamorphosis has run its full course. The landscape of Eastern Nigeria is today dotted with royal palaces and castles, with well-groomed princes waiting in line for their turn to ascend the (British-created) sacred thrones of their ancestors.

One particularly sad aspect of the dark history of European colonialism in Africa was the trans-Atlantic slave trade. Beginning from the mid 1980s till now, prominent Africans at home and in the diaspora have been agitating for the need for Europeans in Europe and America 
to pay massive reparations to the descendants of Africa, for the systematic, large-scale colonial exploitation of Africa, and the unprecedented savagery of the ensuing slavery. However, one dimension of the issue that is yet to be properly confronted by the Africans themselves is the part some of their own people and socio-political institutions might have played in facilitating the pernicious objectives of colonialism and slavery. In this regard, it would be very instructive to know what roles Africa's traditional rulers played in the process. Did they do anything to protect their subjects against the scourge of slavery? Were they just unconcerned bystanders? Or, worse, did they actively deploy the resources of their offices as paramount rulers in the service of the international commerce in live human beings?

Another period I propose to look at is the era of military dictatorships. Consequent upon the attainment of political independence by many African states, there was a rash of military coups d'état, resulting in the overthrow of civilian governments and the establishment of military dictatorships in many African states. The last three decades of the twentieth century were the decades of military regimes all over Africa. During that period too, the collaborationist thesis was fully exemplified. Many African traditional rulers proved to be useful instruments for the consolidation of military rule, just as their forebears had proved to be the handy tools of colonial exploitation. It seems that our traditional rulers are equal opportunity collaborators. They are ever ready to collaborate with the oppressors of their subjects, whether the oppressor is a local or foreign actor, without regard to race, or creed. As Alao puts it, 'Because it lacked popular democratic support and legitimacy, the military depended almost exclusively on the traditional chieftaincy institution in the same way the British did. Military leaders therefore manipulated the traditional rulers to widen the base of their support in the inordinate search for legitimacy' (ibid p. 27).

The atrocities that military dictators perpetrated all over Africa are too well documented to bear any elaborate recitation here. Whether in Idi Amin's Uganda, Mobutu's Zaire, or Sani Abacha's Nigeria, the damage in terms of human suffering and the looting of national wealth was extensive. And we must also reckon with the more fundamental ideological harm in the form of the abortion of the germs of our democratic cultures. In many of these African states the wounds are still fresh. It goes without saying that any group of individuals or institutions (traditional or whatever) that provided the military power-usurpers the po- 
litical platform and the moral succour to establish their reign of terror would be equally culpable for the sins of the military.

A summary of the discussion thus far is in order. The objective of this section of the paper is to articulate a case against the traditional kingship institution. I have argued that the institution is founded on some form of historical injustice or another, or that it derived from a piece of intellectual fraud. I have also argued that not only has the institution not conferred any significant benefits on African societies, when compared to the corresponding institutions in Europe, for example, but that at various points in the history of African societies, the institution has actually been of absolutely negative value, i.e., when it became a ready instrument in the hands of the destroyers of our societies.

Notwithstanding the persuasiveness of the case I have been trying to build against it, I should acknowledge the fact that voices - and these are by no means mean voices - have been raised in the defence of the traditional kingship institution. I propose next to examine the argument in defence of the institution by one of Africa's foremost philosophers, professor Kwame Appiah.

The question for Appiah is the same for us: what to do with our traditional rulers? Appiah (2001) starts with a review of some models that have been suggested. There was President Museveni's proposal of 'a cultural model'. Under this proposal, Africa's traditional rulers would be allowed to operate only within the cultural sphere; the mobilisation of the resources of the institution of traditional rulers for any other purpose and especially for political purposes would be strictly forbidden. Next is Ajume Wingo's suggestion that the traditional institutions be made to serve as 'theatres of civic pedagogy' (Appiah 2001: 46). In this role, traditional rulers can mobilise resources for public purposes, such as education, health, sport, etc (Appiah 2001: 46). Appiah considers neither of these models suitable. For one thing, it must be noted, Appiah says, that allegiance to the traditional kingship institution, unlike membership and participation in a civic organisation, 'is not strictly voluntary' (ibid p.47). Second, and more pertinent, is the fact that the institution itself is now firmly embedded within the framework of modern constitutional and legal provisions. To that extent, it is already inherently political (ibid p.48).

So, what model to adopt? What is to be our attitude toward the traditional kingship system? Appiah starts his defence of the institu- 
tion with the acknowledgement that the "[African] practice of monarchy both offends liberal principles and reinforces illiberal views' (ibid p.50) because 'the practice of monarchy lends symbolic support to and reinforces certain forms of social hierarchy that do not comport well with liberal insistence on the equal dignity of all persons' (ibid). Nonetheless, Appiah says, with specific reference to the kingship institution in his native Ghana, that he could feel no 'urgency of republican sentiments in Asante' (ibid p.53). In fact, he contends that 'it seems wrong to go immediately from the way in which the Asante kingship offends liberal principles to the conclusion that we should abolish it ...' (ibid). Outright abolition of the kingship institution, Appiah argues, would deny society of a number of important benefits. In the first category are the material benefits whose provision may be coordinated through the offices of the Asantehene, for example. The second is the significance of the kingship institution 'for the central liberal value of self-respect' (ibid). Appiah's point is that the institution of monarchy plays a major role 'in the constitution of the self-respect of Asante men and women' (ibid p50). And self-respect is acknowledged by liberal theorists as an important good.

Appiah does not state in any helpful detail the features of the Asante kingship - in the past or at present - which would make it the epitome of cultural pride and the determinant of the self-respect and personal identity of the Asante man or woman of today. He claims that the Asante monarchy possesses 'symbolic legitimacy', and that Asante men and women identify themselves as the heirs to 'a rich tradition'. But, 'symbolic legitimacy', 'rich tradition', and such sundry notions sound like codes. Appiah will have to flesh out in more specific detail the precise import of these rather abstract categories.

For example, what enduring structures of a great civilisation were erected under the inspiration and sponsorship of the Asante kinship institution? How many invading forces of European colonialists were successfully beaten back by the Asante army, under the command of the Asantehene? On whose side was the Asante kingship during the colonial era - the Asante people or the British Administrators? On whose side was the kingship institution during the decades of military dictatorship in Ghana - the people or the generals? If by an act of the Ghanaian legislature, the Asante kingship system were to be abolished today, what specific negative consequences would befall the ordinary Asante men and women on the streets of Kumasi and elsewhere? 
I suspect that the answers to these questions would be similar to the answers to them in other parts of Africa. I agree with Thomas Jefferson that a monarchy cannot confer any benefit on a people, it can only be a burden on their backs. Thus, if it is indeed the case as Appiah claims, that today's Asante men and women still regard the Asante monarchy as the symbol of their identity and the source of their self-respect, that would be most unfortunate. I should see nothing in that institution for an ordinary Asante person, who is not a member of the royal lineage, to identify with or conceive as the basis of her self-respect.

It is interesting to note that Appiah himself is not entirely comfortable with the continued existence of the Asante kingship institution. While asserting 'a substantial commitment to the present of the Asante monarchy', Appiah also nurses 'the hope that as time goes on, [the Asante monarchy] will wither away because the needs that it meets today will be met by the institutions of the increasingly democratic society that Ghana will become' (ibid p.53). Appiah can only hope that his present commitment to Asante kingship and his hope that it will some day wither away, supplanted by the liberal institutions of a democratic Ghana, are not inconsistent (ibid).

But if the central thesis I defend in this paper, namely, that republicanism is a pre-condition for democracy, is correct, then Appiah's 'commitment' and his 'hope' must be mutually inconsistent. As long as the Asantehene is able to run some kind of parallel government over his subjects, the Ghanaian democracy will remain an uncompleted and uncompletable project. Every inch ceded to the monarchy is an inch lost to the republic; a loss to the republic is a loss to democracy. It is not enough to hope that the traditional kingship institution will wither away, overwhelmed perhaps by the forces of democratic modernism. The monarchists would want to preserve their institution and the privileges they derive from it for as long as they could. That is the least we could expect. It would therefore be in their interest to frustrate the process Appiah envisages, whereby the expansion of democracy will result in the diminution of the monarchy.

The capacity of the traditional kingship institution to undermine democratic progress would be significantly enhanced in large, ethnically diverse federal states, such as Nigeria. In a federal system, the centres of authority and power are already constitutionally fragmented. A federal state, as Justice Anthony Kennedy of the United States Supreme Court once remarked, is a system where the atom of sovereignty 
is split. ${ }^{9}$ My contention is that traditional rulers constitute an additional layer of governance, one which by its nature can only complicate the task of national integration. The reason is that the interests and aspirations of the various traditional rulers would run contrary to the republican ideals on which a modern democracy should be anchored. It should come as no surprise, therefore, if, as is presently the case in Nigeria, the various monarchies and other indigenous chieftaincy institutions have served as rallying points for the promotion of parochial ethnic agendas.

Using the considerable resources still entrusted to their care, the traditional rulers can create a lot of static and tension in the system, the culmination of which would ultimately delay national integration. It is unrealistic to expect that the various traditional kings and chiefs in Nigeria, for example, would consider it in their respective interests if Nigerians begin to develop primary allegiance as citizens of Nigeria instead of as the subjects of their kings and chiefs.

Surely there is a need for legal and constitutional intervention to jump-start the necessary revolution in social and political beliefs and habits. Africans should no longer feel comfortable with defining their identity and self-respect by the fortunes of the traditional kingship institution; they must become proud republicans and democrats. It is to some details of the legal and constitutional measures needed to facilitate that process of political re-orientation that I turn in the third and final part of the paper.

\section{Perfecting Our Republics}

A 'republic', according to Webster's New Collegiate Dictionary, is 'a state in which the sovereign power resides in a certain body of the people (the electorate), and is exercised by representatives elected by, and responsible to them' (1959: 719). Republicanism is, therefore, the political philosophy whose basic tenet is the belief that sovereignty derives ultimately from the people, not from God or other supernatural forces, nor from some hereditary institution or principle. As I observed earlier in this paper, nearly all African nation states today proclaim themselves republics. For example, Nigeria formally adopted a republican constitution in 1963, three years after securing political independence from Great Britain. Many other African states followed a similar pattern of political progression. 
The actual situation on the ground, however, belies a serious commitment to that republican proclamation. In most cases what obtains is the adoption - partly deliberate, partly by default - of a mixed constitution. The trend has been to try and synthesise elements of the traditional kingship system with republican principles. The institution of traditional rulers has proved to be resilient indeed. And like the weed in the vineyard, the traditional kingship system will continue to grow and stifle the life of our republican democracies, unless a determined effort is made to uproot it. The founding fathers of the American Republic understood that all too well. The framers of the American Constitution took necessary measures to ensure that the monarchy would never again have a foothold in their land. As the Americans did more than two centuries ago, modern African nation states must adopt appropriate constitutional devices to immunise their republics against the pernicious effects of monarchies.

The first constitutional measure required is to vest the locus of sovereignty in the people by denying it to any other institution. The abolition of the monarchy should be made justiceable. Second, constitutional provisions should be made making religion strictly a private affair, through the express prohibition of state sponsorship of religion, or the establishment of state religions. Third, since traditional rulers depend on the permanent pool of indigenes of their respective domains for their supply of subjects, concerted efforts should be made through appropriate legislation to abolish the indigene/settler dichotomy. Modern African constitutions should provide for the 'continuous' residence in any part of a country (over a prescribed number of years) to confer nativity, not mere citizenship of the place. Better still, nativity and citizenship should confer identical legal and political status. Fourth, among other requirements, inclusion in a federation should be conditioned on a region or community's willingness to endorse, strictly, these principles of secularism in matters public.

Other measures such as programmes of rapid industrialisation, appropriate civic education as part of the school curriculum, and in general, rapid expansion of literacy, would also help to propagate the republican creed.

In concluding I again acknowledge how the thesis of this paper might cause cultural purists some distress. The suggestion that we go all out to abolish the traditional kingship institution may scandalise some, especially coming from an African. In their view, what I advocate would 
amount to putting our traditional values down in order to promote foreign or western ideas and values. In his discussion of these issues with particular reference to the situation in South Africa, Joe Teffo, to cite one example of a cultural purist, considers it 'more disheartening that it was the blacks themselves who tended to undermine their own traditional institutions on which African societies are anchored' (Teffo 2002: 4). But there is really no basis for this 'us' versus 'them' mentality and the accompanying sentiments. As a constitutional philosophy, republicanism is by no means a stranger to Africa. There were clear instances of pre-colonial African states organised along strict republican lines of popular sovereignty, and where political leaders were regarded as no more than trustees of the people's power and authority; certainly not as the legally-illimitable owners of the earth. A good example, as I noted above, was traditional Igbo society in south-eastern Nigeria, i.e., before the colonialists's clumsy intervention at social engineering which gave the Igbos kings and crown princes.

I see nothing inherently African in the tenacious advocacy on behalf of the anachronistic traditional kingship institution. The monarchy was not an original invention of Africa. Surely there can be nothing unAfrican or foreign in the republican creed which identifies the people as the bearers of sovereignty, and which provides that all public offices and positions must be aspired to and occupied, at least in principle, strictly on the basis of merit and fair competition.

\section{Notes}

1. By 'Africa' in this paper, I will be referring primarily to sub-Saharan Africa.

2. To be sure, there are some 'fundamentalists', to use Wingo's label, of the first type, who call for a return to the 'glorious past' of the traditional chieftaincy institution. According to Ajume Wingo, Mwangi S. Kimenyi is one scholar who advocates 'the complete return to pre-colonial boundaries'.

3. This description is contained in Jefferson's letter to James Madison, January 30, 1787. Parts of the letter are reproduced in Richard H. Popkin and Avrum Stroll, eds., Philosophy and Contemporary Problems - A Reader, New York: Holt, Rinehart and Winston, 1984, p. 394.

4. The Governor of Oyo State, Senator Rashidi Ladoja, has declared, not too long ago, that he is number nine in the queue while his political godfather, Alhaji Lamidi Adedibu is number six.

5. This section of the paper draws heavily on the writings of Professor J. A. Atanda, formerly of the Department of History, University of Ibadan, Nigeria. The works include, Atanda, J. A., An Introduction to Yoruba History, Ibadan: University Press, Ibadan, 1980; Atanda, J. A., 'The Historian and the Problem of 
Origins of Peoples in Nigerian Society', Journal of the Historical Society of Nigeria, vol. X, No. 3, Dec. 1980; Atanda, J. A., 'The Origin of the Yoruba Reconsidered', Odu: A Journal of West African Studies, New Series No. 25 (January 1984), pp. 3-19. Other works of similar interest include, Biobaku, S. O., Lugard Lectures: The Origin of the Yoruba, G. P., Lagos, 1955. Among pioneering works of more general interest is Samuel Johnson's History of the Yoruba, Lagos, 1921.

6. Oduduwa is fondly called Atewonro - one who came climbing down on an iron chain.

7. Ile-Ife literally translates as the place from where the earth began to spread.

8. I am grateful to my colleague, Dr Akin Alao, of the Department of History, Obafemi Awolowo University, Ile-Ife, Nigeria, for making available to me an unpublished manuscript of his. This portion of the paper draws from his work.

9. Justice Kennedy made this observation in his concurring opinion in US Term Limits, Inc. v. Thornton. (514 U.S.779, 115 S. Ct. 1842). The full statement is worth quoting:

'Federalism was our nation's own discovery. The Framers split the atom of sovereignty. It was the genius of their idea that our citizens would have two political capacities, one state and one federal, each protected from incursion by the other. The resulting Constitution created a legal system unprecedented in form and design, establishing two orders of government, each with its own direct relationship, its own privity, its own set of mutual rights and obligations to the people who sustain it and are governed by it'.

\section{Reierences}

Alao, A., 'Power and Privilege in African Politics: Chieftaincy Conflicts Among the Yoruba of South-Western Nigeria', unpublished manuscript.

Akinyele, S. A., 1971, Revolution and Power Politics in Yoruba Land, 1840-1893; Ibadan Expansion and the Rise of Ekitiparapo (Ibadan History Series), London: Longman.

Appiah, K. A. 2001, 'Ethnic Identity as a Political Resource', in Teodros Kiros, ed., Explorations in African Political Thought. New York: Routledge, pp. 45-53.

Atanda, J. A., 1980, An Introduction to Yoruba History, Ibadan: University Press

Atanda, J. A., 1980 'The Historian and the Problem of Origins of Peoples in Nigerian Society', Journal of the Historical Society of Nigeria, Vol. X, No. 3, Dec

Atanda, J. A., 1984 'The Origin of the Yoruba Reconsidered', in Odu: A Journal of West African Studies, New Series No. 25, pp. 3-19.

Biobaku, S. O., 1955, Lugard Lectures: The Origin of the Yoruba, G. P., Lagos.

Johnson, S., 1921, History of the Yorubas from the Earliest Times to the Beginning of the British Protectorate, Lagos: CMS.

Popkin, R. H. and Stroll, A., eds., 1984, Philosophy and Contemporary Problems - A Reader, New York: Holt, Rinehart and Winston.

Popkin, R. H, 1968 'Scepticism, Theology and the Scientific Revolution in the Seventeenth Century', in Problems in the Philosophy of Science, Amsterdam: NorthHolland Publ co, pp. 1-39.

Teffo, J., 2002, 'Monarchy and Democracy: Towards a Cultural Renaissance', Journal of African Philosophy, vol. 1, no. 1 p. 4. 
Wingo, A. H, 2004, 'Fellowship Associations as a Foundation for Liberal Democracy in Africa', in Kwasi Wiredu, ed., A Companion to African Philosophy. Oxford: Blackwell Publishing Ltd. 
